\title{
Soil and vegetal shifts in meadows under conditions of alluvial lithogenic matrix on islands in the delta of the Northern Dvina River
}

\author{
Tatyana Parinova *, Irina Amosova, and Elena Nakvasina \\ Northern (Arctic) Federal University named after M.V. Lomonosov. Higher School of Natural \\ Sciences and Technologies. Department of biology, ecology and biotechnology. Arkhangelsk, \\ Russian Federation
}

\begin{abstract}
In this paper we represent the results of our research: a scheme of plant and soil succession changes on the alluvial lithogenic matrix in the zone of river and marine accumulation in the delta of the Northern Dvina river. We used more than 1000 geobotanical and 200 soil descriptions. The succession scheme of the transformation of meadow communities in the river accumulation zone is represented in this work. This scheme occurs both in the natural processes of phytocenosis and soil development, as well as in agrogenic influence, as well as a number of successional changes during formation of meadows in the zone of marine accumulation.
\end{abstract}

\section{Introduction}

In the European part of Russia, communities of the forest zone formed on the alluvial lithogenic matrix. Temperate climate causes an extensive development of mesophytic grass, shrub and tree vegetation. The delta of the Northern Dvina located on the border where the influence of the river itself meets the one of the White Sea. There is a multitude of islands in the delta where developed areas combine with natural ones. Natural and anthropogenic processes define a specific scheme of changes in soil-vegetation cover.

According to the botanical-geographical division of the Russian Federation, the research area is located within the Eurasian taiga (coniferous-forest) area. It has a zonal type of northern European spruce forests and intrazonal type of meadow vegetation.

Natural and climatic conditions in the area, combined, affect negatively on the distribution of meadow vegetation. But due to the specific ecological conditions in the delta, this influence partially overlaps, which makes it possible to spread primary and secondary meadows in high latitudes. Intensive use of meadows (as hayfields, pastures, arable land) and then a sharp decline in agriculture in the late XX - early XI century caused various changes in the ecological, floristic, productive, structural features of communities. Seaside meadows, as a rule, are not in use and are subject to natural changes.

Soil and vegetation cover of the islands in Northern Dvina delta has been studied fragmentarily. In the middle of the XX century a team of the Soil Science Department and

\footnotetext{
*Corresponding author: nadeinata@mail.ru
} 
the soil and agronomic museum of the TSAA (now the Russian State Agrarian University named after K.A. Timiryazev) have carried out significant field work to survey the soils and vegetation cover of the meadows from the delta of the Vychegda River and to the sea islands in the delta $[1,2]$. T.A. Parinova, E.N. Nakvasina, O.V. Sidorova provided recent ecology-floristic characteristics of flood meadows in the lower reaches of the Northern Dvina [3]. There are available point data for marshes and flood-meadows in Arkhangelsk region, mainly its mainland [4-6]. A group of researchers examined flood-meadows in the Murmansk region in detail [7-9].

\section{Materials and Methods}

Our research focused on two types of islands in the delta of the Northern Dvina in the Arkhangelsk region (North-West of the European part of the Russian Federation). T.A. Parinova and E.N. Nakvasina studied islands in the zone of river accumulation. (Islands: Andrianov, Lastolsky, Chubnavolskaya Koshka, etc.). E.Yu. Churakova and I.B. Amosova studied islands in the zone of marine accumulation (Golets, Kumbich). We investigated floristic composition and soils in those communities, using standard geobotanical methods. The majority of communities belong to the meadow type of vegetation. In total, we analyzed more than 1000 geobotanical descriptions, including 786 descriptions on trial plots of $1 \mathrm{~m}^{2}$ and 250 descriptions on trial plots of $100 \mathrm{~m}^{2}$. The names of the species of vascular plants are given in accordance with the summary of S.K. Cherepanov [10]. The names of mosses are in accordance with the list of mosses of Eastern Europe and Northern Asia [11]. We placed more than 200 basic (full-profile) soil sections and 100 extended soil sections. Classification and diagnostics of soils aligned with the classification of soils of 2004 [12].

\section{Results}

Based on the conducted studies, we constructed a general scheme of successive shifts in the conditions of the alluvial lithogenic matrix in the delta of the Northern Dvina River on the islands in the zone of river and marine accumulation (Figure 1). The fact that these shifts occur simultaneously with the combined effect of continental (zonal) conditions on the catchment area of the river and the erosion-accumulative and flood-alluvial activity of the river itself complicates the scheme above. This generally takes place in the context of the formation of the segmented floodplain of the Northern Dvina as a meandering river. Natural successional scheme violated through anthropogenic activities.

\section{Discussion}

In the zone of marine accumulation, seaside meadows emerge as primary meadow communities. These communities have limited distribution and small area, confined to the stony and sandy substrate of the islands in the White Sea and the loamy and clay substrates of the mainland. Seaside meadows are represented by mesophytic plant communities formed outside the tidal zone. Salty waters come here only during heavy storms. Meadows are located on the leeward sides of the islands - eastern (Mudyug Island) and south-western (Kumbish Island). This type of plant communities predominantly forms a narrow strip, with a width of $50 \mathrm{~m}$, rarely extend to $100-200 \mathrm{~m}$ between marshes, and birch or pine forests. Seaside meadow communities are most well represented on the river alluvium of the maritime terrace of Kumbish island. They develop on peaty and sandy substrata. The total projective coverage is $40-55 \%(\max =90 \%)$. Such communities differ in relatively small 
height of the grass stand $30-40 \mathrm{~cm}$. The species saturation in these communities is small, 15-20 species on average. There are no clearly expressed dominants in the grass stand, mainly the grasses predominate. Therefore, such communities are very bright and diverse. The most typical species are Trifolium pratense L., Hylotelephium triphyllum (Haw.) Holub, Rumex acetosa L., Rumex crispus L., Oberna behen (L.) Ikonn., Dianthus superbus L., Stellaria graminea L., Tanacetum vulgare L. and others. The grains are represented by: Alopecurus arundinaceus Poir., Anthoxanthum odoratum L. and several plants of the Poa species. The peculiarity of seaside meadows on this territory is the presence of species usually growing on salinized marshes (Potentilla egedii Wormsk., Plantago maritima L., Puccinellia coarctata Fern. \& Weath.) and forest communities (Avenella flexuosa (L.) Drej.). The presence of halophytic species in the communities is due to the regular impact of sea water during particularly high tides and heavy storms.

The succession of vegetation within the sea and river terraces that have emerged from the main zone of the sea's influence is closely related to the relief conditions (elevation height above sea level), the nature of moistening, the degree of salinity of the substrate, and soil-forming processes. The climax and pre-climax vegetation is confined to absolute heights within the islands. Pioneer groups occupy silty drains, flooded with water at least twice a day. Plants do not form closed communities and are represented by single-or smallscale communities. Mostly in this zone grow such species as Salicornia europaea L., Ruppia brachypus J. Gay, Puccinellia coarctata Fernald \& Weath., Agrostis stolonifera L., Juncus filiformis L. In some cases, thickets of Phragmites australis (Cav.) Trin d. ex Steud. and Bolboschoenus maritimus (L.) Palla may appear.

Marshing communities occur in small areas of 5-20 m from the water. Marshes are formed in a zone of periodic salinization, at least twice a year they are under water for a short time. Soil type - peaty or soddy silty substratum. This type of coastal communities is formed by halophytic and halomeophyte groups. Communities are small, the most common species of this zone are Alopecurus arundinaceus, Atriplex nudicaulis Bogusl., Honckenya peploides (L.) Ehrh., Lathyrus maritimus Bigel., Leymus arenarius (L.) Hochst., Plantago maritime L., Triglochin maritimum L., T. palustre L.

Seaside meadows are in the zone of episodic salinization - during severe storms, in 50$150 \mathrm{~m}$ from the water. Soils are sod-peaty. Formed mesophilic and halomezophilous plants, with some inclusion of halophytes (Triglochin maritimum, Potentilla egedii, etc.). In some cases, a narrow strip of meadow (not more than $50 \mathrm{~m}$ wide) is formed behind the meadows on a sandy substrate. Forest communities - birch forest or pine forests on dunes are formed in 150-200 m away from the water. Pine forests are located on the highest parts of the islands.

Most of the meadow communities in the zone of river accumulation in the delta of the Northern Dvina by their origin take an intermediate position between the primary and secondary community, since they have a dual exo-endodynamic genesis. Meadows appear as primary stages of vegetation, mainly on newly formed substrates (sand banks). Their existence is sustained as a result of anthropogenic-related activities (mainly grazing and mowing). The true secondary meadows that emerged from under the coniferous forest were not marked in the delta (in none of the soil profiles there are signs of podzol formation).

Transformation processes in soil and vegetation cover are interrelated. In the zone of river accumulation, soils are formed on modern alluvial deposits of different granulometric composition under the influence of three soil-forming macroprocesses: sod, meadow and marsh [13]. Due to the features of the slime, sandy or loamy soils predominate on various islands, often with visible signs of gleying. They are subject to regular flooding by flood waters and a deposition of fresh layers of alluvium on the soil surface. These processes determine their specific peculiarities of structure, water regime and genesis. Alluvial soils 
are "young", characterized by high biogenicity and intensity of soil formation, very diverse in regime, structure and properties.

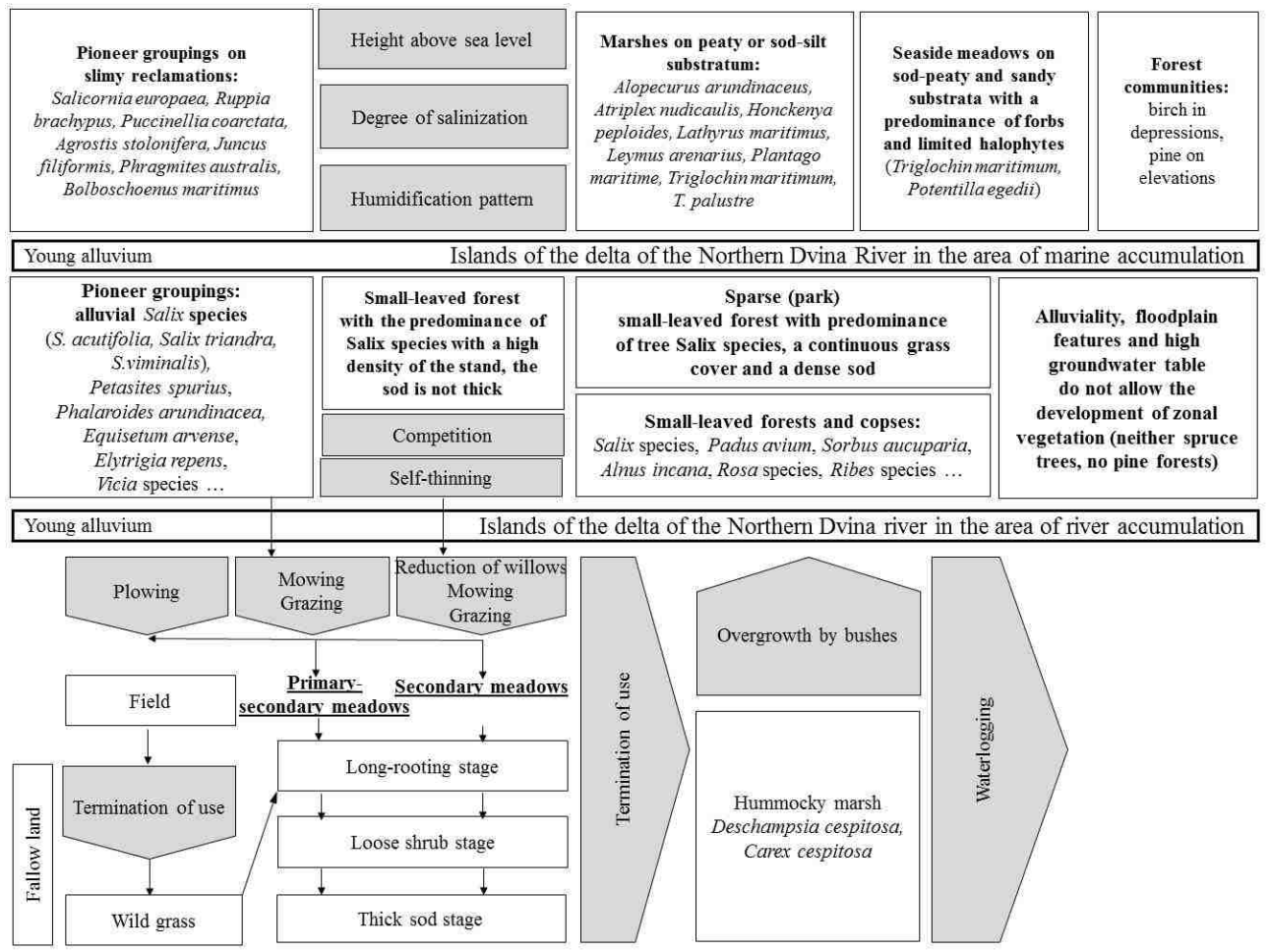

Fig. 1. Vegetative shifts on the alluvial lithogenic matrix in the zone of river and marine accumulation in the Deltaof the Northern Dvina River.

Without economic use under natural development, small pioneer communities in about 10 years are replaced by small-leaved forest with a predominance of Salix species with a high density of stand. As a result of competition and self-thinning, such communities pass to the stage of rarefied small-leaved forest with predominance of Salix species with treelike forms, grassy cover with apparent sod. The herb layer is dominated by: Elytrigia repens, Calamagrostis epigeios (L.) Roth, Veratrum lobelianum Bernh., Urtica dioica L., Filipendula ulmaria (L.) Maxim., Aegopodium podagraria L., Chrysosplenium alternifolium L., Thalictrum simplex L., Lysimachia vulgaris L., Vicia sepium L. and sometimes Matteuccia struthiopteris (L.) Tod. Richness of species of herbaceous layer per $100 \mathrm{~m}^{2}$ is $7-10$ species. The tree layer is represented by: Salix acutifolia Willd., S. caprea L., S. pentandra L., S. triandra L., S. viminalis L. with an admixture of Alnus incana (L.) Moench, occasionally A. glutinosa (L.) Gaertn. The shrub layer: Sorbus aucuparia L., Padus avium Mill., Ribes rubrum L. and R. nigrum L. Moss layer: Amblystegium serpens (Hedw.) Bruch et al., Plagiomnium ellipticum (Brid.) T. J. Kop., Brachythecium rivulare Bruch et al., Climacium dendroides (Hedw.) F.Weber \& D.Mohr. At this stage, the community comes to a dynamic equilibrium and can exist for many decades.

Economic activity violates the natural change of communities. In the past, alluvial lands in the delta were actively used as hayfields, pastures and arable land. Now they are almost all abandoned. Fallow communities in the delta experiencing regenerative shifts, which include the classical stages: weedy, rhizome, loamy and dense-bush. 
Plowing and formation of fallow soils disrupt the natural course of soil changes. Selfregeneration of fallow soils follows the sod type. The analogue of the sod horizon - upper layer old plow horizon, densely intertwined with roots, begins to isolate itself in the first 10 years after the cessation of plowing. The signs of arable land in the upper horizons of soils are preserved up to 30-40 years and can be registered in deeper layers of the humus horizon compared to native soils, in the dark (black-brown) color of the mixed horizon and its even lower boundary. The disturbance of the activity of meliorative systems, widespread in the delta of the river. Northern Dvina, can lead to bogging flood-ground waters. In this case, gleying starts to develop in the lower horizons of the soil, and the erosion and erosion of the lower boundary of the humus (old-plow) horizon. As a result of self-restoration, arable soils undergo the stage of degraded soils (30-40 years), then they pass into subtypes of postagenogenic soils, the formation of which can follow an automorphic type (with the maintenance of the meliorative system) or hydromorphic (in violation of it), approaching the original (native ) soils. There are probably two variants of the evolutionary development of soils during postagrogenesis and their transition to the native state: alluvial postragrogenic serohumus (peat) gley; alluvial postgragenic gray-humus.

Thus, the presented scheme reflects the main directions of soil-plant changes in the delta of the Northern Dvina. We have described four large shifts of natural origin in the marine accumulation zone and 3-4 natural shifts in the river accumulation zone. Anthropogenic transformation causes up to 9 different shifts.

This project is supported by grant from the Russian Foundation for Basic Research (RFBR) and the government of Arkhangelsk region № 17-44-290111 (project manager: Prof. Elena Nakvasina).

\section{References}

1. G.V. Afanasyev, Reports of the TSHA 3, 259-264 (1957)

2. G.V. Afanasyev, Reports of the TSHA 34, 193-198 (1958)

3. T.A. Parinova, E.N. Nakvasina, O.V. Sidorova, Meadows of the lower reaches of the lower reaches of the Northern Dvina (NArFU, 2013)

4. A.A. Korchagin, Scientific papers of Institute of the Academy of Sciences of the USSR 2, 223-344 (1935)

5. V.M. Shmidt, V.G. Sergienko, Vestn. Leningr. un-ta 21, 48-55 (1984)

6. E.Yu.Churakova, O.V. Sidorova, I.B. Amosova, Scientific notes PetrSU 2 86-98 (2016)

7. N.V. Babina, Vegetation of Russia 3, 3-21 (2002)

8. N.E. Koroleva, S.V. Chinenko, E.B. Sortland, Phyto diversity of Eas. Eur. 9, 26-62 (2011)

9. L.A. Sergienko, Composition and structure of vegetative cover of coastal ecosystems of the Russian Arctic (Petrozav. state. un-t, 2012)

10. S.K. Cherepanov, Vascular plants of Russia and neighboring countries (Cambridge University Press, 1995)

11. M.S. Ignatov, O.M. Afonina, E.A. Ignatova, Arktoa J. 15, 1-130 (2006)

12. L.L. Shishov, V.D. Tonkonogov, I.I. Lebedeva, Classification and diagnostics of soils in Russia (Ojkumena, 2004)

13. G.V. Dobrovolsky, Soils of the river floodplains of the center of the Russian Plain (MSU, 2005) 